\title{
Air Pollution Measuring techniques and impact on our environment
}

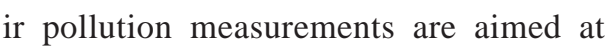
improving our understanding of the chemical and physical properties of
\end{abstract} the atmosphere, thus addressing essentially three issues with very different space and time scales:

- measurement of critical or peak values of air pollutant, close to local emission sources in densely urbanized or industrialized sites,

- long term observation and trend analysis on air quality,

- caracterization of photochemical pollution (smog) episodes on a time scale of a few days, with field campaigns aimed at creating a "base case" database for the validation of atmospheric models describing our atmosphere. When such models are able to reproduce adequately the base case, they constitute the only scientifically relevant tool to predict the impact of different air pollution abatement strategies.

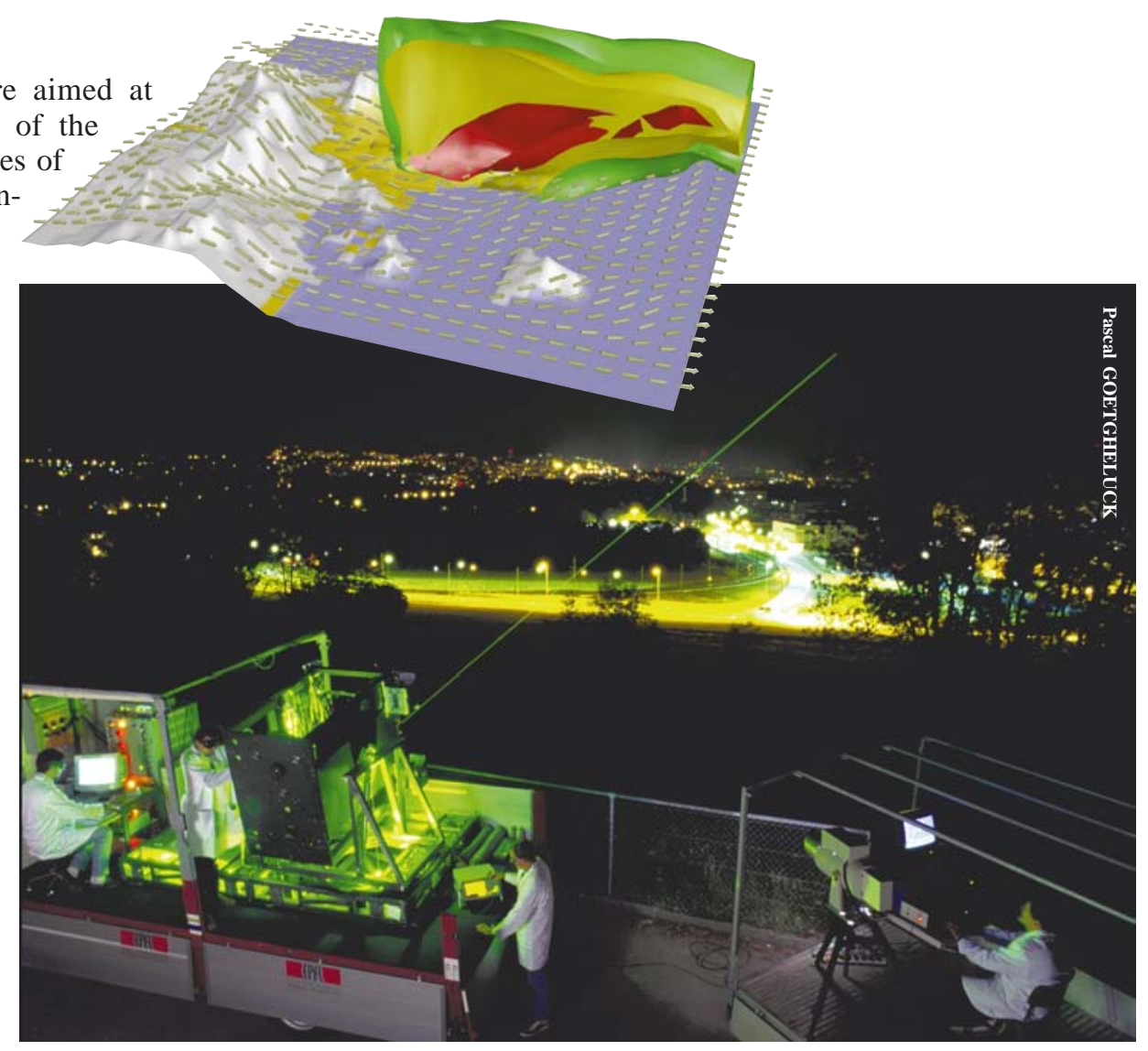

Along with these three issues as a

guideline, this Dossier came up from the workshop "Air Pollution: Measuring Techniques and Impact on Our Environment" organized by EPFL and held at Lausanne in October 1998. Some specific developments in air pollution monitoring and wind measurement are presented, and also the first results of a field campaign held in April-June 1998 in the Milan area. The impact of air pollution on our environment is investigated by addressing the specific effect of ozone on agriculture, a work which underlines the variability of these effects with different type of plants.

Some of the most recent developments in air pollution science are well represented in the manuscripts collected for this Dossier, and their authors are warmly thanked for providing these relevant contributions.

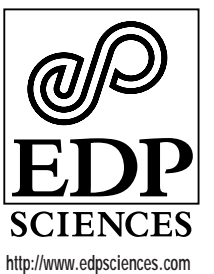

\section{WILEY-VCH}

Coordinated by: Bertrand Calpini

Swiss Federal Institute of Technology EPF Lausanne, Switzerland

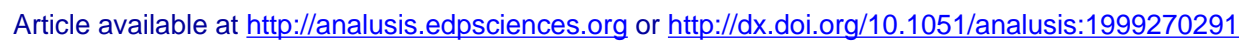




\section{Air Pollution/ Pollution de l'air}

\section{Foreword}

Air pollution. Measuring techniques and impact on our environment B. Calpini

293 Pollution de l'air : méthodes de mesure et impact sur notre environnement B. Calpini

302 Surveillance of air pollution: Some reflections on its actual state and future needs W. Baehler

305 Planetary Boundary Layer ozone fluxes from combined airborne, ground based lidars and Wind profilers measurements

P. Quaglia, G Larchevêque, R. Jimenez, B. Lazzarotto, V. Simeonov, G. Ancellet, H. Van den Bergh and B. Calpini

310 Use of a wind profiler in a planetary boundary layer experiment D. Ruffieux

313 Evidence of primary air pollutant reduction and photochemical pollution enhancement after opening a road tunnel to the public

R. Jiménez, H. van den Bergh and B. Calpini

319 Airborne measurements of $\mathrm{NO}_{y}$ and impact of this trace gas on atmospheric chemistry P.E Perros and T. Marion

325 Examples of the importance of trace gas measurements in the Milan ozone plume A. Neftel

328 Direct measurement of the total reaction rate of $\mathrm{OH}$ in the atmosphere B. Calpini, F. Jeanneret, M. Bourqui, A. Cappier, R. Vajtai and H. van den Bergh

337 Évolution de la teneur en composés aromatiques des aérosols urbains au cours d'une journée. Étude par spectrométrie de masse à deux lasers O.P. Haefliger, T.D. Bucheli et R. Zenobi

340 Electron microscopy for the characterisation of atmospheric particles P.A. Buffat

347 The development of a Nafion based amperometric carbon monoxide sensor for domestic safety

P.D. van der Wal, N.F. de Rooij and M. Koudelka-Hep

351 Radon measurements in dwellings: Study in the Vaud canton (Switzerland) T. Buchillier and J.-F. Valley

355 Effects of air pollutants on plants $J$. Fuhrer and P. Bungener 